\title{
THE STRATIGRAPHY AND TECTONICS OF THE RAUTUVAARA IRON ORE DISTRICT, NORTHERN FINLAND
}

\author{
AIMO HILTUNEN and MIKKO TONTTI
}

\begin{abstract}
HILTUNEN, AIMO and TONTTI, MIKKO 1976: The stratigraphy and tectonics of the Rautuvaara iron ore district, northern Finland. Bull. Geol. Soc. Finland 48, 95-109.

The sedimentary rocks of the Rautuvaara iron ore district constitute an epicontinental association that, from oldest to youngest, comprises quartzites, quartz-feldspar schists, carbonate and skarn rocks with their associated magnetite mineralisations and amphibolites. They are overlain by Kumpu-formation. The magnetite ores are strata-bound skarn ores. The Taporova hematite deposit seems to represent a different sedimentary facies.

It is possible that there were at least two deformation phases in the region, the first of which was marked by the intrusion of monzonite, regional metamorphism under conditions of the amphibolite facies, the formation of skarns and the accumulation of ore material.

The NE-SW trending valley of the river Äkäsjoki is marked by the presence of a prominent fault and shear zone.
\end{abstract}

Aimo Hiltunen, Rautaruukki Oy, SF-96100 Rovaniemi 10, Finland Mikko Tontti, Department of Mining and Metallurgy, Helsinki University of Technology, SF-02150 Espoo 15, Finland

\section{Introduction}

In this article the Rautuvaara iron ore district is understood as the area composed of supracrustal and intrusive rock types that covers some $270 \mathrm{~km}^{2}$ of northern Finland and includes the commune of Kolari and also part of that of Muonio. Deposits with several types of iron ore have been discovered in the district (Fig. 1); the majority of them are magnetite deposits associated with a long skarn rock formation, or its contact, overlying quartzite. The most important deposits of this type are the magnetite ores of Rautuvaara and Hannukainen. Other less signifi- cant deposits from north to south are Tuohilehto, Rautuoja, Rautuhelukka, Sainkangas and Juvakaisenmaa.

In 1975 a mine was developed at Rautuvaara for the exploitation of several separate magnetite ore bodies, which contain about 15 million tons of ore assaying 30 to 50 percent iron. The bulk of the Hannukainen orebodies were found in 1974-1975 and accurate information on their ore reserves is not yet available. Estimates indicate, however, that the reserves amount to several tens of million tons of ore assying 30 to 45 percent iron.

The Rautuvaara iron ore district includes 


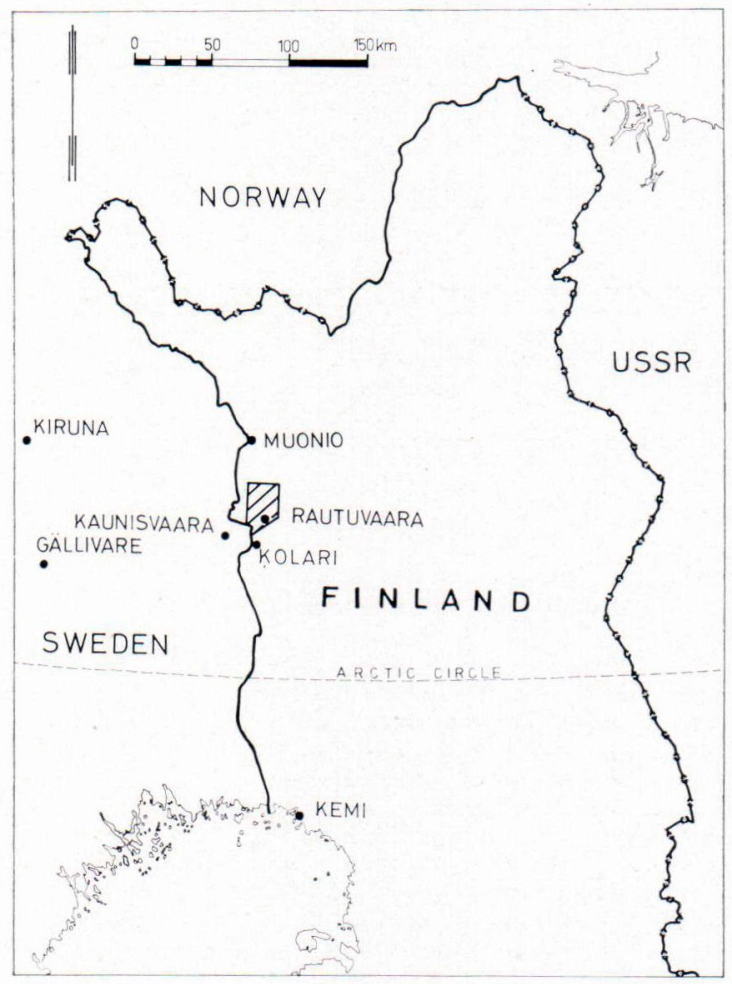

Fig. 1. The location of the investigation area.

not only iron ore deposits in the skarn horizon but also a magnetite deposit associated with the Sivakkalehto scapolite amphibolite, the Taporova-Suuoja hematite deposit, which is in mica schist, and the small quartzbanded iron ore deposit at Ristimella.

The present study is based on investigations carried out in the Rautuvaara region in the summer of 1974. The mapping was done in cooperation with the Exploration Department of Rautaruukki Oy. and the Ore Data Register Project initiated by the Ore-geological commission of Northern Finland. The latter was largely responsible for the mapping south of the river Äkäsjoki, and the Exploration Department of Rautaruukki Oy. for the northern part of the region.

The aim of the study is to present a coher- ent picture of the rock types in the Rautuvaara region and to examine their stratigraphy and tectonics. Since the investigation of the ore deposits has not yet been completed, detailed descriptions of the ores and ore geological problems are not included, and the ore deposits are described in the context of the rock type descriptions.

The geological map (Fig. 3.) is based on exposure mapping, on diamond drillings and on the interpretation of geophysical maps, i.e. airborne magnetic and electric and ground magnetic, electric and gravimetric maps.

Although the Juvakaisenmaa deposit, one of the ore deposits in the Rautuvaara iron ore district, has been known since the 17 th century, it was not studied until 1917, when L. Borgström started investigations at the deposit and in the environment. During the Second World War Vuoksenniska Oy. carried out investigations in the region, and from 1956 to 1960 the Rautuvaara area was studied in more detail by Suomen Malmi Oy. It was during this second period that the inventory of southwestern Rautuvaara was completed and that of Kupari-Rautuvaara started. The mine patents and claims were transferred to Otanmäki Oy. in 1960, which continued investigations throughout the $1960 \mathrm{~s}$. The main target of the feasibility studies was on the Rautuvaara ore, but later as the decision to start mining was postponed, the company extended prospecting into the environment. In 1967 Otanmäki Oy. was amalgamated with Rautaruukki Oy. and since 1970, when it was decided to construct a mine, investigations have continued under the name of Rautaruukki Oy. In 1974 investigations were reopened in the Hannukainen area.

The Rautuvaara iron ore district has been discussed earlier in publications by L. H. Borgström 1928, E. Mikkola 1941, K. Schmidt 1960, T. Mikkola 1960, H. Stigzelius and P. Ervamaa 1962, and A. Shaikh 1964. 


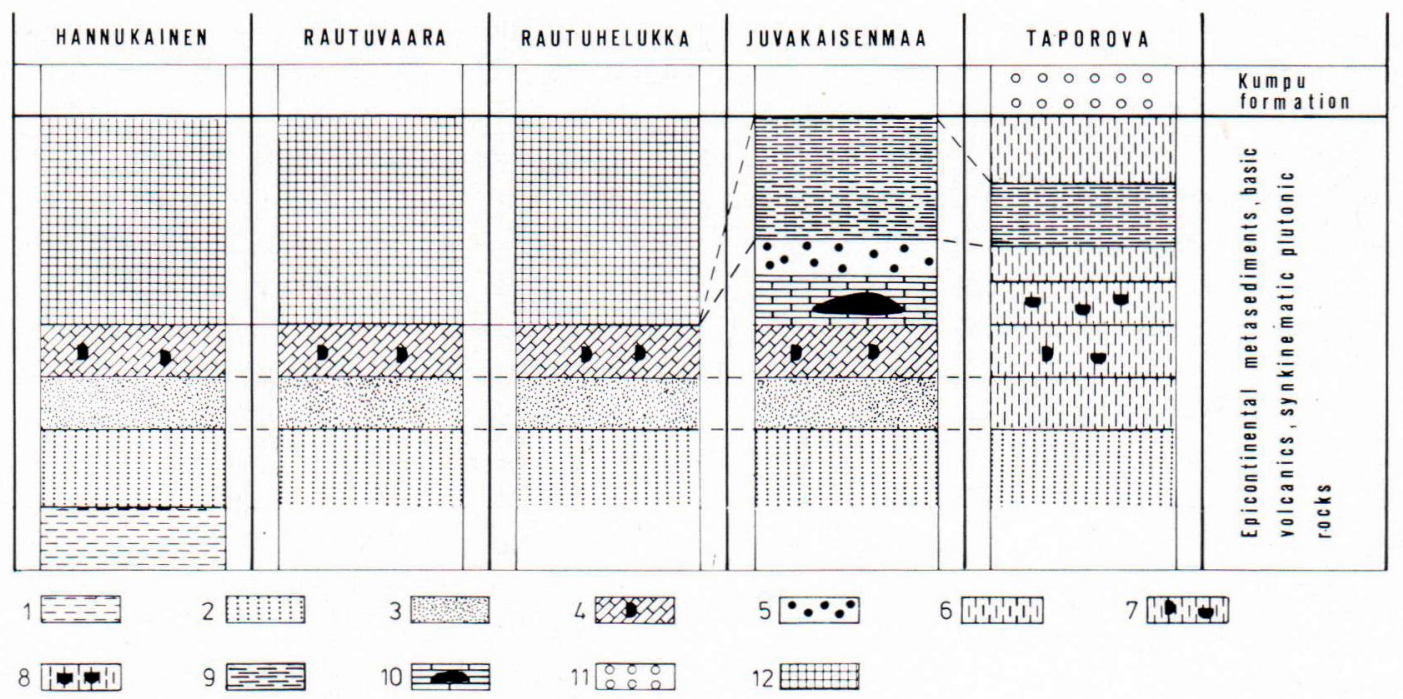

Fig. 2. Schematic stratigraphy of the Rautuvaara iron ore district.

1. Calcium silicate-bearing gneiss

2. Quartzite, older

3. Quartz-feldspar schist

4. Skarn, magnetite ore

5. Ristimella iron formation

6. Mica schist

7. Mica schist, magnetite- and hematite-bearing

8. Mica schist, hematite-bearing

9. Amphibolite

10. Carbonate rock, graphite-bearing schist

11. Quartzite, conglomerate (Kumpu formation)

12. Monzonite

\section{Stratigraphy and petrography}

The stratigraphy of the region can be simplified as follows:

Top

quartzite, conglomerate (Kumpu-formation) amphibolites

skarn rocks, limestones, skarn iron ores, quartzbanded iron formation

quartz-feldspar schists, mica schists

older quartzite

calcium silicate-bearing gneiss (only at Hannukainen)

\section{Bottom}

The stratigraphy of the Hannukainen, Rautuvaara, Rautuhelukka, Juvakaisenmaa and Taporova areas is presented in greater detail in Fig. 2. Between Hannukainen and Kuertunturi beyond the investigation area and underlying the older quartzite is a Ca-silicate-bearing gneiss.

Essential to the stratigraphy of the area is the fact that only one skarn horizon, which contains the iron ores, has been established with certainty. Locally this horizon is split up by monzonite sills. In the Juvakaisenmaa area there is doubt as to whether two or more skarn horizons are present, or whether the same horizon repeats itself as a result of intensive folding. The latter alternative would seem the more likely if it is assumed that the skarn ores are of sedimentary origin.

\section{Supracrustal rocks}

\section{Older quartzite}

The older quartzite, which is heterogenous in both structure and texture, is stratigraphically the lowest known rock in the investigation area and is encountered in the eastern and southeastern part of the area. Its thickness is not known, but it is assumed to be a 
few hundred metres. In places skarn, mica gneiss, hornblende gneiss and amphibolite are visible as interbeds varying in thickness from 30 to $40 \mathrm{~m}$ at the most.

Almost glassy and only slightly schistose types of older quartzite are encountered, but also migmatitic beds are often met with. Recrystallisation of quartz and potash feldspar is common. Cataclastic structures and mylonites occur locally. Even so the primary bedding is still visible in places.

The older quartzite, which locally displays intense granitisation, is generally a mediumgrained and pinkish or violet (non-granitised type) rock. In addition to the main minerals quartz and potash feldspar, biotite and muscovite (sericite) are encountered, particularly in the migmatitic, gneissose and most intensely granitised parts. The most characteristic of the accessories is sillimanite.

\section{Quartz-feldspar schist}

Although the rock described as quartzfeldspar schist varies widely in composition and texture, it underlies the skarn formation as a fairly coherent stratigraphic unit.

There are only a few observations of the rock from outcrops, and the information is based mainly on drilling data, which indicate that the thickness of the schist is some tens of metres at the most.

At its purest it is a fine-grained rock, grey in colour and often with pronounced bedding. Characteristic of the quartz-feldspar schist is the grading into skarn rock; this commences with the appearance of the skarn minerals as bands or dissemination in the schist. As the amount of skarn increases it may form layers as much as several metres in thickness. The most common skarn mineral is diopside, but amphibolerich layers are also present, in which case the composition of the rock approaches that of amphibolite.
The dominant mineral in the quartz-feldspar schist is potash feldspar, usually microcline. There is distinctly less plagioclase and in composition it is albite-oligoclase. Despite the name of the rock, quartz is sparse and may be even totally lacking in places, hence quartz-feldspar schist is not always the correct name. Locally the schist contains appreciable amounts of graphite; in this case some iron sulphides, mainly pyrrhotite, are also present. Furthermore, varying amounts of biotite, cummingtonite, actinolite and diopside are met with. The accessory minerals are titanite and sporadic scapolite and tourmaline.

\section{The skarn rock association}

Stratigraphically the skarn rock zone forms an extensive horizon from a few metres to more than a hundred metres in thickness overlying the quartz-feldspar schist. On the map the skarn rock zone progresses from Tuohilehto to Hannukainen and Rautuoja; it then turns northeast to Rautuvaara and Rautuhelukka. From here the map shows the zone continuing to the southwest, which part of the map was drawn largely on the basis of geophysical interpretations. The Juvakaisenmaa ore deposit is well exposed.

The zone has been investigated by diamond drilling at Tuohilehto, Hannukainen, Rautuoja, Rautuvaara, Rautuhelukka, Sainkangas and Juvakaisenmaa. Conform monzonite sills divide the zone into parallel sections, at least at Hannukainen and Rautuvaara. In the northern part of the region the skarn zone is overlain by a conform monzonite intrusion, which thus disrupts the sedimentary series. In the southwestern part of the region the skarn rocks are overlain by amphibolites.

In composition the skarn rocks display great variation. The following types may be distinguished on the basis of the main com- 
ponents: diopside skarn, hornblende-diopside skarn and hornblende skarn, in which case the composition of the rock approaches that of amphibolite. The most common type is banded hornblende-diopside skarn, which in addition to hornblende and diopside also contains plagioclase and locally scapolite. The accessory minerals are quartz, titanite, apatite, biotite, chlorite, serpentine, epidote, garnet and tourmaline. The diopside skarn is composed almost totally of diopside that has partly altered into hornblende.

There are also amphibolites associated with the skarn zone. These are greenish, schistose and banded. The main minerals are hornblende, plagioclase (oligoclase-andesine), diopside and biotite, as well as occasional magnetite and scapolite. The mutual abundances show considerable variation. Some biotiterich types have been encountered that macroscopically are indistinguishable from mica schists. In other places the amount of magnetite is so great that the rock is a low-grade ore. In one site an amphibolite type was met with which contained hypersthene and amphibole of the cummingtonite-grünerite series as main minerals in addition to those given at the beginning of the paragraph. In southwestern Rautuvaara a main mineral of a rock included in this zone is olivine that evidently is of metasomatic origin.

The magnetite ores associated with the skarn zone are conform lenses or slabs whose longitudinal axes are conformable with the general regional SW-plunge of lineation in the area. The ores of the skarn zone have been considered as strata-bound ores by T. Mikkola (1960) in his interpretation of the Kolari ores. Lindroos (1974) and Frietsch (1966) share the same opinion about the skarn iron ores of Kaunisvaara and Svappavaara in northern Sweden.

The magnetite deposits of Tuohilehto, Hannukainen, southwestern Rautuvaara, northeastern Rautuvaara, Rautuhelukka and Ju- vakaisenmaa are distinctly associated with the skarn zone. The Rautuoja and KupariRautuvaara deposits are disseminated mineralisations at the contact of the monzonite with the skarn zone.

In addition to predominant magnetite the skarn ores contain varying amounts of pyrrhotite and pyrite, and locally also chalcopyrite. The iron tenor ranges from 30 to 45 percent $\mathrm{Fe}$, depending on the orebody, and the sulphur content from 1.5 to 4 percent S. The magnetite at Kupari-Rautuvaara occur together with chalcopyrite as a dissemination in a massive albite-anthophyllite rock. The grade fluctuates between 15 and 25 percent $\mathrm{Fe}$ and 0.28 and 0.8 percent $\mathrm{Cu}$. At Rautuoja only modest tenors and tonnages have been established; the deposit is largely of the Kupari-Rautuvaara type.

A peculiarity revealed by diamond drilling at Hannukainen and Rautuhelukka is the sporadic occurrence of molybdenite and uraninite in the lower part of the skarn layer near the contact with quartz-feldspar schist.

\section{The Ristimella iron formation}

The Ristimella iron formation in the southwestern part of the region is located at the centre of a synform and apparently has the same stratigraphic position as the skarn iron ores of the Rautuvaara region. The rock is a quartz-magnetite-banded and folded variety that locally displays intensive disharmonic folding as a result of which the bands are often broken. Cataclastic features are common. The formation is small in size, being 20 to $30 \mathrm{~m}$ thick at the most, and it has a low iron content. There are diopside skarn and limestone beds on either side of the formation which stratigraphically are probably part of the skarn zone described previously.

The mineral composition of the Ristimella deposit is simple. In addition to quartz and 
magnetite, cummingtonite is encountered, even in abundance in some places. The cummingtonite imparts a greenish hue to the rock. The most important accessories are titanite and biotite.

\section{Amphibolites}

Amphibolites are encountered most abundantly in the southern parts of the investigation area, where they are obviously derived from basic to intermediary volcanites. They consist of homogenous, massive and only slightly schistose types as well as conspicuously schistose, banded and folded types. Stratigraphically they are all included in the younger rocks of the area.

Homogenous amphibolites in the southern part of the investigation area are fine- to medium-grained rocks and grey or greenish in colour. The main minerals are plagioclase and hornblende as well as occasional diopside and biotite. Sometimes potash feldspar (granitised types) and quartz may be counted among the main minerals. Hornblende and diopside occur as clusters, the hornblende being apparently an alteration product of diopside. The accessories include apatite and sporadic magnetite, scapolite and baryte. The homogenous type is slightly foliated, but the lineation, which is a common structural feature in the area, is not discernible.

The banded and distinctly schistose type of amphibolite is common in the southwestern part of the area where outcrops abound. It is a greenish and fine- to mediumgrained rock. The banded texture is due to the alternation of dark-coloured, garnet-rich and light-coloured quartz-rich garnet-free bands. In places quartz is so abundat that the rock may more fittingly be designated hornblende gneiss than amphibolite. Other main minerals are plagioclase $\left(\mathrm{An}_{20-40}\right)$ and hornblende as well as occasional diopside and biotite. Magnetite occurs as a random accessory. The nature of the amphibolites has been described in greater detail by Shaikh (1964).

Mica schists and the associated TaporovaSuuoja hematite mineralisations

At Taporova in the western part of the investigation area there is a region of mica schist with which the hematite mineralisations of both Taporova and Suuoja are associated.

The hematite deposit of Taporova is located in a syncline with mica schist as the lowermost rock. The mica schist is overlain by hematite-bearing schists, which in turn are overlain by amphibolite and mica schist. The schist formation is crosscut by a pink microcline granite, which lies mainly parallel to the jointing and perpendicular to the fold axis of the syncline.

In mineral composition the mica schist is a quartz-rich, relatively fine-grained and grey-coloured rock with alternating quartzand mica-rich layers. In places sillimanite and cordierite are met with. In addition to hematite, the hematite-bearing schist contains magnetite, quartz, potash feldspar, muscovite and plagioclase. Minor amounts of tourmaline, apatite, titanite, zircon and chlorite are also encountered. It should be mentioned that the magnetite content is highest in the lowest parts of the syncline and decreases upwards until this mineral is almost completely lacking from the hematite schist proper. The iron content ranges from 15 to 30 percent Fe. Some parts of the Taporova hematite schist are also baryte-bearing.

The stratigraphic position of the hematite deposits of Taporova-Suuoja in relation to the skarn ores is not clear. Although they seem to be the result of different sedimentation conditions, a different stratigraphic posi- 
tion is not necessarily implied (T. Mikkola 1960).

\section{Scapolite amphibolite}

This is the name given to a rock at Sivakkalehto in the southeastern part of the investigation area. Its stratigraphic position is uncertain but it is apparently one of the younger rocks in the area. Structurally the scapolite amphibolite is very heterogeneous. In some portions it is unfoliated and homogeneous and is consequently reminiscent of a plutonic rock. Locally it is intensely deformed, schistose and of rodgneiss appearance. Structures have also been encountered that resemble intrusive (eruptive) breccias. A tectonic origin is not to be discounted.

The main minerals of the scapolite amphibolite are scapolite, biotite, diopside, hornblende and plagioclase in varying abundances. The dark minerals, particularly diopside, tend to occur as porphyroblasts. Locally some almost monomineralic scapolite rocks are also met with. The most common accessories are magnetite and the apatite associated with it. Chalcopyrite occurs as a random ore mineral. Other minerals present are anhydrite, baryte, zeolites and carbonates.

The scapolite amphibolite may contain magnetite in such abundance that the rock may be ranked as an ore. It should be remembered that the highest aeromagnetic anomaly in the Rautuvaara area is at Sivakkalehto and that the existence of the magnetic anomaly has been known since the beginning of this century (e.g. Borgström 1928). So far, however, drilling has not revealed a coherent ore deposit.

The origin of the scapolite amphibolite is unknown, but its present appearance is evidently a product of intense metasomatism. This is supported by the revelation in thin section of some grains in which the poly- synthetic twinning of plagioclase is still dimly perceptible beneath the scapolite habit. Even so, the fact that the scapolite is at least partially of primary origin should not be disregarded. Serdyuchenko (1975) has proposed that the scapolite-bearing rocks evolved from evaporites including some of those in northern Sweden.

The extent of the scapolite in the Rautuvaara region is not definitely known owing to the difficulty of distinguishing it macroscopically from feldspar. Consequently, all the rocks of the region, and especially the amphibolites, have to be subjected to detailed examination and dense sampling.

\section{Kumpu-formation}

A younger quartzite with conglomerate interbeds is met with in the Taporova-Tapojoki region at the western margin of the investigation area. This is stratigraphically the topmost rock and may be related to the quartzites designated by E. Mikkola (1941) the Kumpu-Oraniemi sedimentary series. Current usage in Finland prefers the more restrictive name of Kumpu-formation, and this is the term employed in this study. Indications of the relationship are provided by the conglomerate beds, in which e.g. fragments of basic volcanics and red jasper are met with. Especially red jasper fragments are typical of Kumpu-formation (E. Mikkola 1941, p. 182).

\section{Plutonic rocks}

\section{Monzonite}

The bulk of the bedrock of the investigation area is intrusive rock. Although it is indicated on the map as monzonite, it does in fact consist of rocks of varying composi- 
tion. In his explanation to the map sheet Erkki Mikkola (1941) describes these rocks as gneissose calc-alkali syenites, and Shaikh (1964) employs the term granodiorite gneiss. One of the most common types, and that which is monzonite proper in composition, is a pink, homogenous and medium-grained rock comprising 60 to 80 percent feldspars (of which potash feldspar 50 to 75 percent). The composition of plagioclase varies, being $\mathrm{An}_{5-25}$. The most common of the dark minerals is hornblende, although minor amounts of biotite and diopside are also encountered. Some quartz is almost always present, and may even be as much as 2 to 10 percent, in which case the rock is quartz monzonite. The mutual abundances of the feldspars vary, the amount of plagioclase often being in excess of potash feldspar. Accessory minerals are titanite, apatite, chlorite, calcite and zircon, as well as some random magnetite, pyrite and chalcopyrite.

The contact of the monzonite with the skarn rocks is generally sharp but, near the contact, skarn inclusions are visible in the monzonite, which differs conciderably in composition from the usual type. This greycoloured variant has often been noted to be several tens of metres thick and more finegrained than the forementioned monzonite. In the field it has been given the name of diorite. The main minerals are plagioclase $\left(A n_{5-20}\right)$, biotite, hornblende and diopside. Some parts of it are marked by the presence of potash feldspar, and in that case it approaches monzonite in composition. The mutual abundances of the main constituents, especially the amounts of the dark minerals, vary, and owing to the ubiquitous lineation and schistosity of the rock the darker monzonite types have often been referred to as amphibolite. In some portions, however, the composition is almost albititic, as in the rock with disseminated magnetite at Kupari -Rautuvaara, which is albite-rich and also contains anthophyllite and cummingtonite. The darkest differentiates encountered in the Rautuvaara mine are reminiscent of gabbro, but their plagioclase is oligoclase in composition.

The boundaries between the diverse types are sharp in some cases but gradual in others. All the rocks described display a close spatial relationship with each other and are of an intrusive nature, hence they are included in the monzonite intrusion as variants produced by differentiation.

The monzonite is generally cut by pegmatite veins which in composition are feldspar- and quartz-feldspar pegmatite. In the opinion of Mikkola (1941), the veins are comagmatic with syenite, but at least at the western edge of the monzonite area they are associated with younger microcline granite.

The monzonite may be described as a synkinematic intrusion commonly dispalying conformable contacts with the sediments. A glance at the map, however, indicates that crosscutting contacts may also have been formed along the fault lines. The monzonite was evidently of significance in the evolution of the ore mineralisations in the area.

\section{Granite}

In the northwestern part of the investigation area there are occurrences of pink granite that displays intrusive contacts with the monzonite, and with the Taporova sedimentary rocks along its southern edge. This granite and the pegmatite associated with it are the youngest rocks in the area. The main minerals of the granite are microcline and quartz. Dark minerals are sparse, mainly being biotite and random hornblende. In the Taporova area a few clusters of uraninite have been observed in the granite veins cutting the schist. 


\section{Tectonics}

The Rautuvaara area is characterised by SW-plunging folds with a distinct lineation and features which are interpreted as results of shear folding. Faulting parallel or subparallel to axial planes is common. The dominant structure is the Rautuvaara-antiform with a NE-striking subvertical axial plane and SW-plunge (Figs. 3 and 4). Deformation occurred possibly in two phases under conditions of high grade amphibolite facies.

The largest fracture zone is along the NEtrending valley of the river Äkäsjoki.

\section{Folding}

North of Äkäsjoki the layers dip $20^{\circ}$ to $30^{\circ}$ to the west and fold axes plunge about $20^{\circ}$ to the southwest. Good examples of these folds, plunging about $30^{\circ}$ to the southwest, are exposed at Taporova.

South of Äkäsjoki the folding has been intense so that the layers dip steeply. The structures of this area were analysed using the GEOKU-computerised mapping system (Gaàl and Suokonautio, 1973). The number of measurements amounts to 886 (Figs. 5 and 6).

The main geometric features of the Rautuvaara-antiform can be deduced from the pidiagrams. The trace of its axial plane runs between diagram areas 9 and 10, the NW-limb dipping $290^{\circ} / 65^{\circ}$ and the SE-limb $130^{\circ} / 70^{\circ}$. The maxima of the pi-diagrams 1 to 10 indicate that in the southwestern part of the area the axial plane cleavage of the Rautuvaara antiform is slightly fan-like. In the NW-limb the dip is $80^{\circ}$ to the southeast (diagrams 4, 5 and 8) and in the SE-limb $80^{\circ}$ to the northwest (diagrams 2 and 3).

The beta-diagrams show clearly that the area is characterised by a SW-plunge of $30^{\circ}$ to $55^{\circ}$. This is in accordance with the measured lineations of the area as seen on the $p i$ - diagrams. An interesting exeption is at Juvakaisenmaa (diagram 3), where beta plunges $059^{\circ} / 14^{\circ}$. This indicates a local culmination southwest of Juvakaisenmaa and a depression between Juvakaisenmaa and Sivakkalehto. Beta-diagrams 4, 8 and 11 do not yield any significant information. It is, however, possible that 4 and 8 with the illdefined maxima indicate subvertical axes which, as it seems, might be related to the strike-slip fault in the Äkäsjoki valley. Beta diagram 9 of the Rautuvaara mine and its vicinity demonstrates a secondary bending around a $178^{\circ} /$ $62^{\circ}$ plunging axis. The corresponding pidiagram illustrates the SW-plunging lineations observed in the field. The scapolite amphibolite body at Sivakkalehto (diagram 1) might be a subvertical $\left(230^{\circ} / 70^{\circ}\right)$ pipe, as is also suggested by the geophysical interpretation.

\section{Faulting}

The dominating fault and fracture zone of the area is the NE-trending Äkäsjoki valley, which extends southwestwards to Suuoja where it is visible in outcrops as a mylonite zone about 30 to $40 \mathrm{~m}$ broad. The mylonite is reddish and composed mainly of quartz and magnetite. The rock gives a distinct linear magnetic anomaly. The forementioned subvertical axes in the betadiagrams 4 and 8 , its attitude parallel with the axial plane of the Rautuvaara-antiform and the magnetite mineralisation indicate a comparatively old age for the Äkäsjoki fault.

Minor NW-striking faults and fractures have been detected on geophysical maps and on aerial photographs. A lefthanded example of these faults can be studied in the exposures of Taporova. The largest is located in the northern part of the region in the contact of monzonite with granite extending southwards as far as the Äkäsjoki. This fault disrupts the 


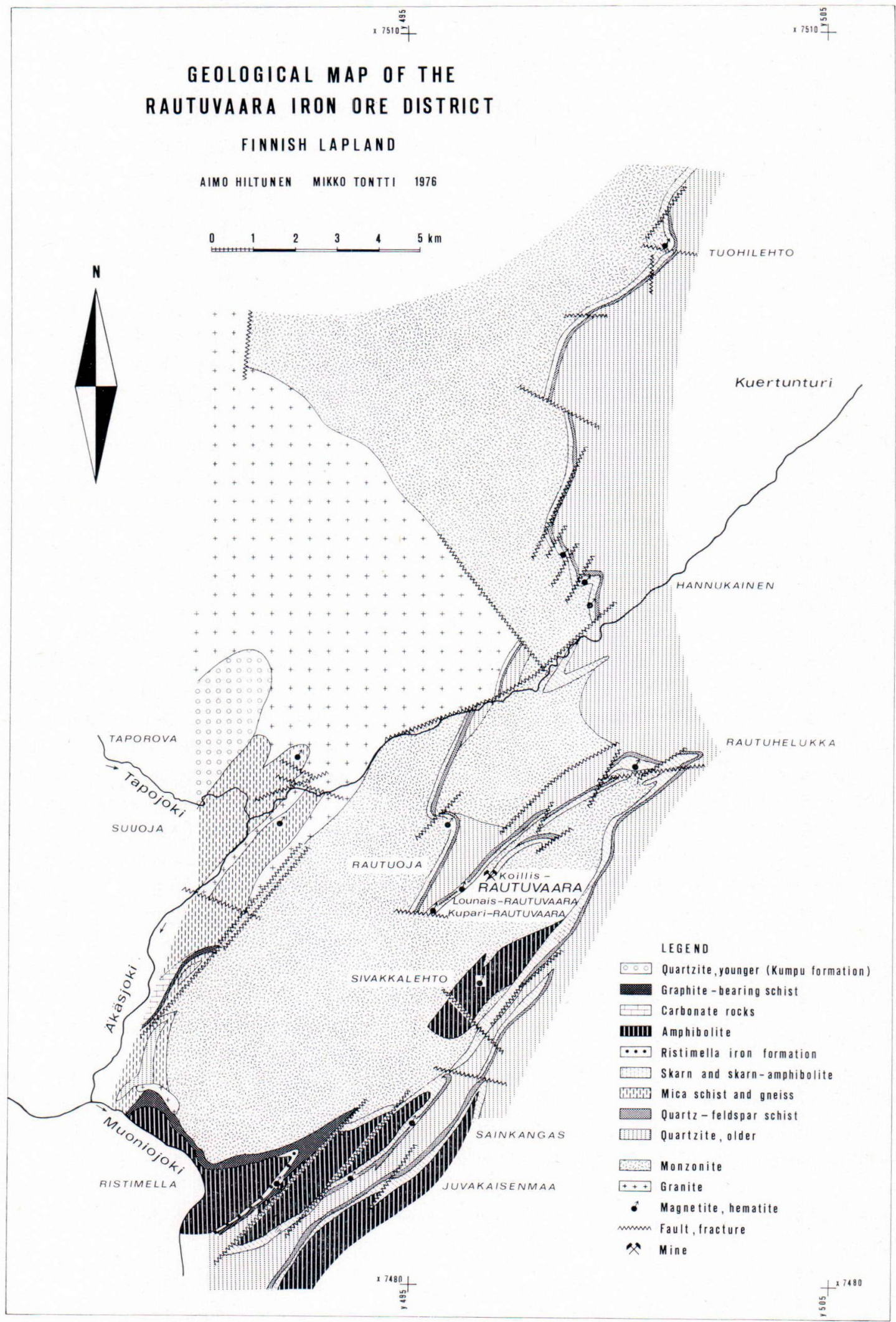

Fig. 3. 


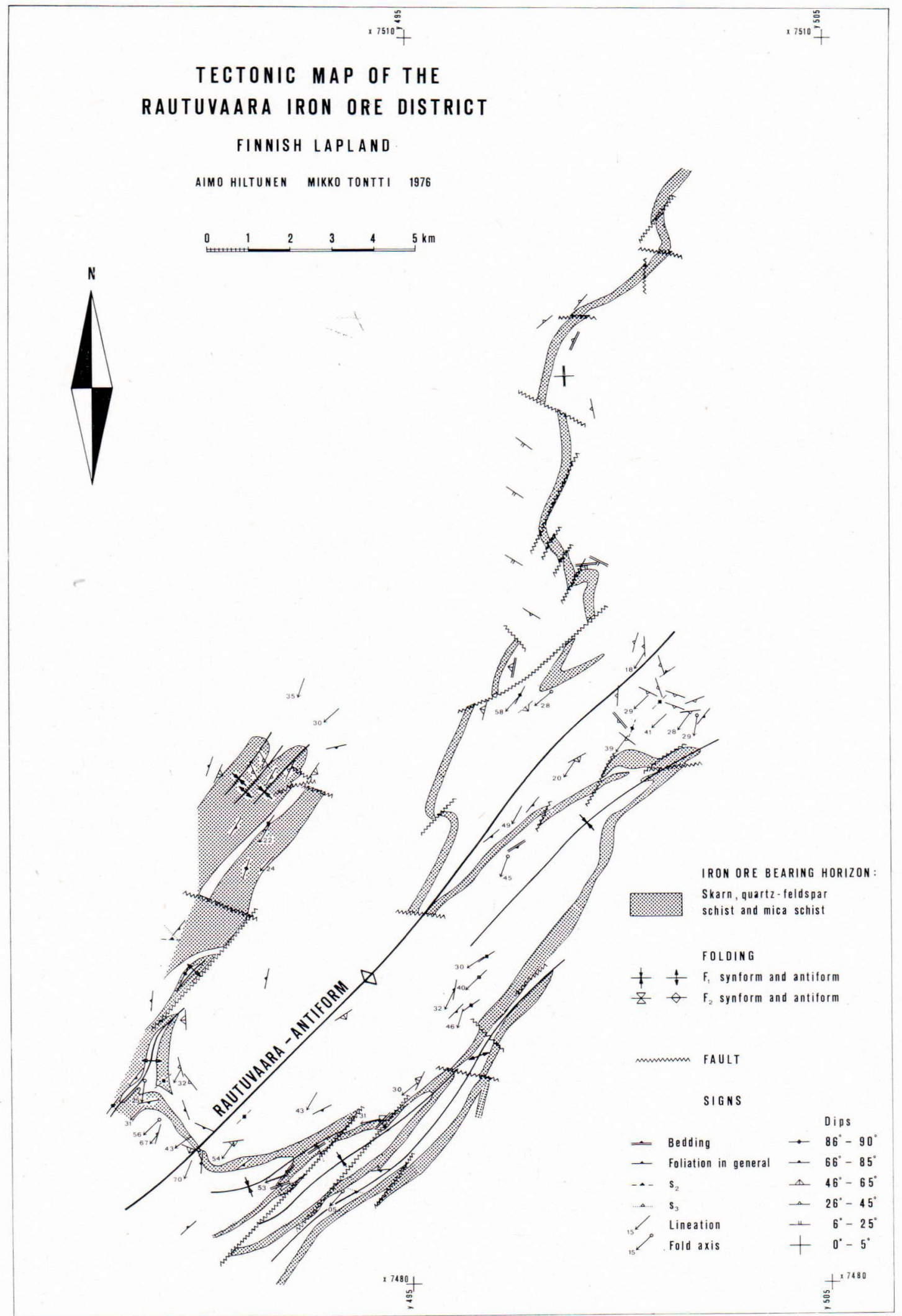

Fig. 4. 


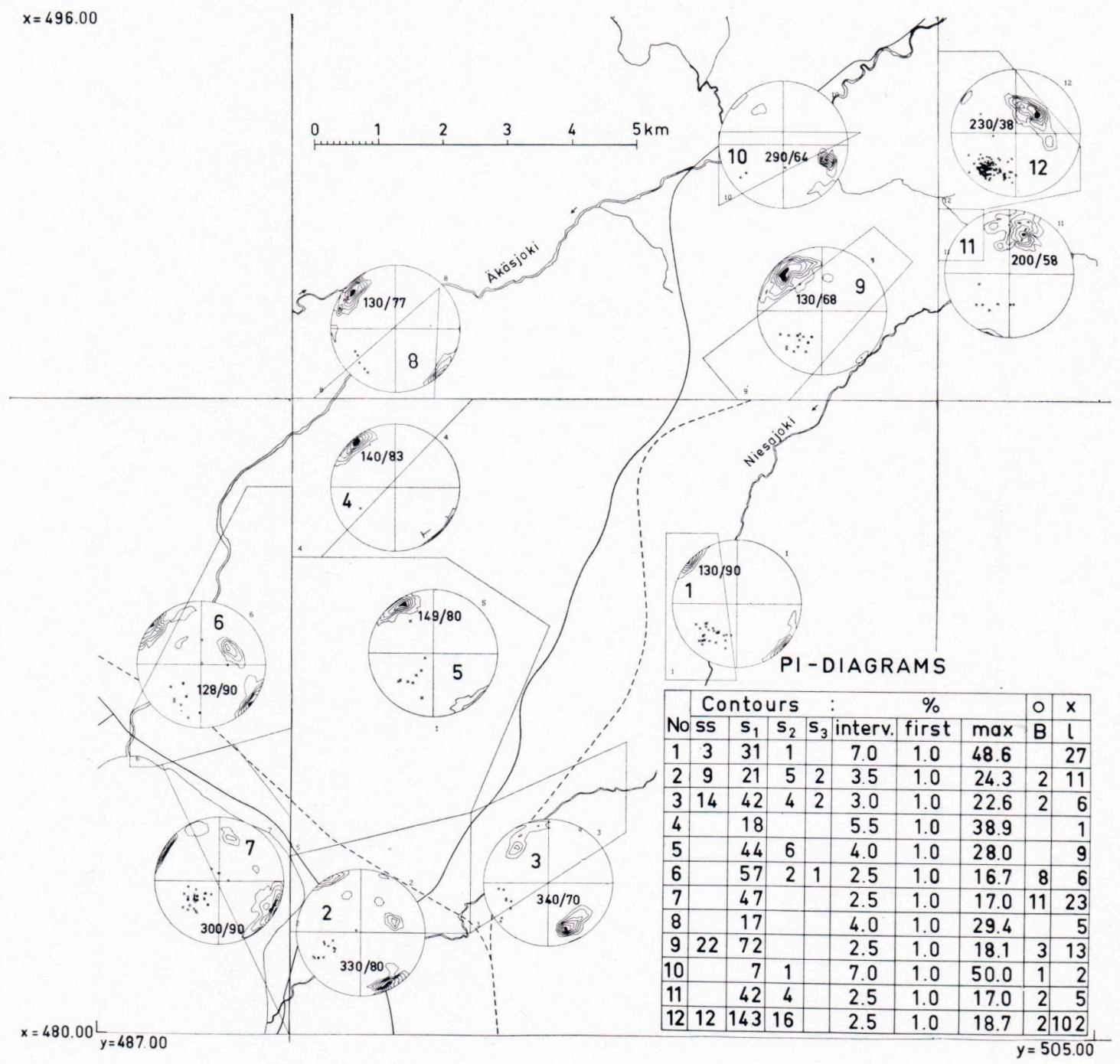

Fig. 5. $\pi$-diagrams of the southern part of the investigation area. Planar elements contoured. Fold axes drawn as small circles, lineations as small crosses.

quartzite and skarn zone that comes from Rautuoja. Diamond drilling indicates that the displacement extends for hundreds of metres.

\section{Interpretation}

The main principal stress acted in a NW$\mathrm{SE}$ direction. The monzonite intruded conformably during the first folding phase in layer-parallel sheets. It exhibits conspicuous synkinematic features with the lineation and foliation parallel to that of the supracrustal rocks. It might also be inferred that the first folding phase and the intrusion of the monzonite were connected with thrusting. For example, at Hannukainen the monzonite lies flat and conformably upon the sedimentary rocks. 


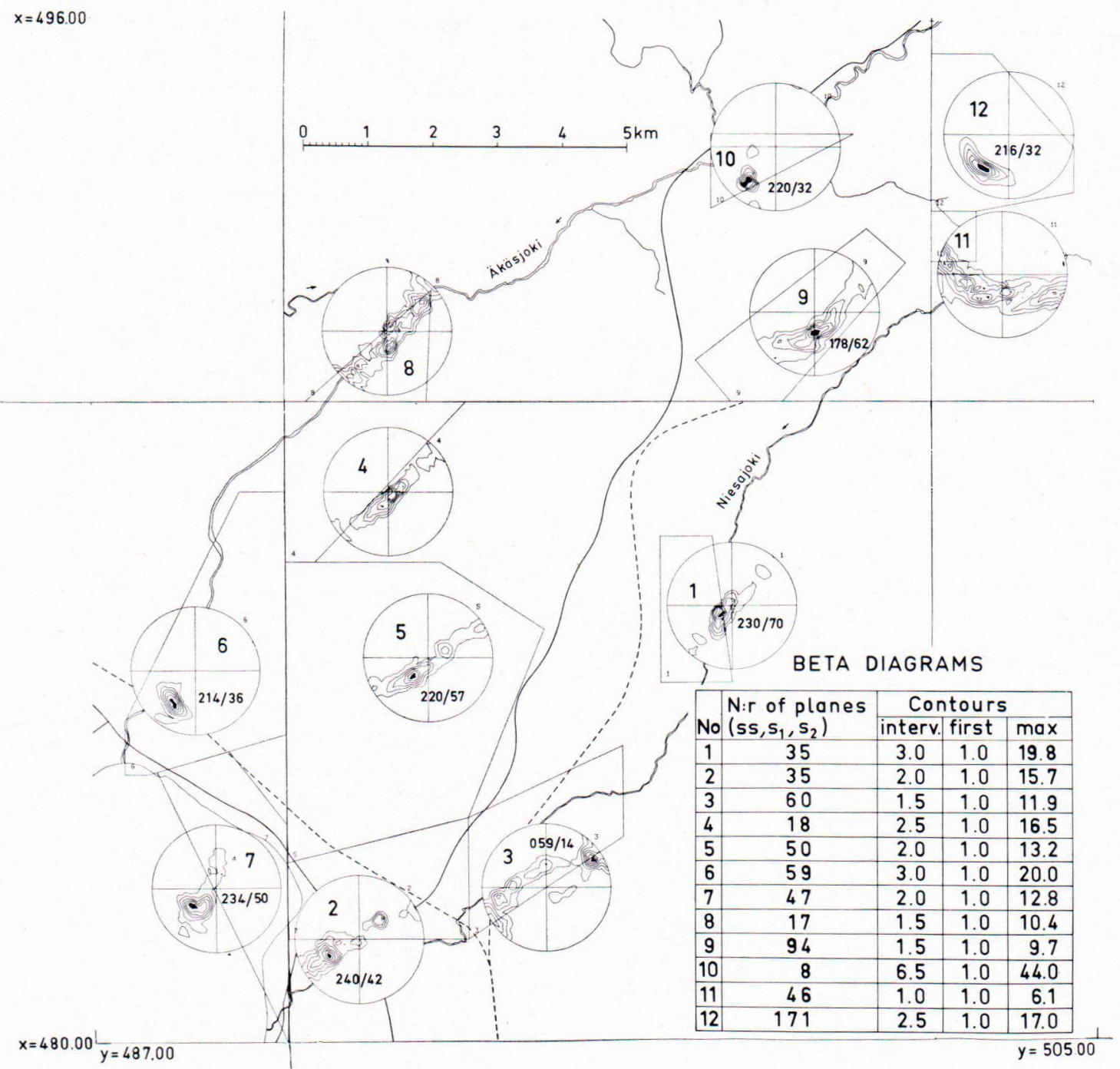

Fig. 6. $\beta$-diagrams of the southern part of the investigation area.

Intensely folded beds of the skarn association cut by numerous small faults parallel to the axial plane have proved to be favourable for the occurrence of ore deposits (Fig. 3). The ore lenses are situated en echelon and are strongly elongated in the direction of the regional plunge. The Äkäsjoki valley probably represents a deep-seated fracture that played a key role in the evolution of the gross features of the area. Even so, the smaller faults associated with the folding were obviously more important for the evolution of the ores.

\section{Conclusions}

The sedimentary rocks of the Rautuvaara iron ore district represent an epicontinental 
association that comprises the following rocks from oldest to youngest: quartzites, quartzfeldspar schists, carbonate and skarn rocks with the associated magnetite deposits, and amphibolites. These are overlain by Kumpuformation. The magnetite ores and mineralisations are strata-bound skarn ores. The Taporova hematite deposit probably represents a different sedimentation facies.

The first deformation phase was evidently marked by the intrusion of monzonite, regional metamorphism under conditions of the amphibolite facies, the formation of skarn and the accumulation of ore material. The monzonite intrusion possibly had some effect on the formation of copper mineralisations in the contact of skarn with monzonite. It is possible that at least one more deformation phase followed later. There is evidence that the fracture and fault zone of the Äkäsjoki was active on several occasions during the geologic evolution of the area. The youngest faults are those bearing SE-NW.

Deposits of the same type as that of the skarn iron ores of Rautuvaara have been found some $20 \mathrm{~km}$ away at Kaunisvaara in Sweden (Lindroos 1974). Features common to both deposits are the high sulphur and low phosphorus content as well as the occurrence of scapolite in the country rock. At Rautuvaara, however, the degree of metamorphism is higher and there are fewer carbonate rocks, the iron ore horizon being composed almost entirely of skarn and magnetite mineralisations. Hence, certain differences may be perceived in the stratigraphy of the areas: the Rautuvaara amphibolites, probably of volcanic origin, overlie the iron ore horizon, whereas at Kaunisvaara the iron ore formation overlies a basic volcanite (Lindroos 1974). A feature peculiar to Rautuvaara and that has not been reported from Kaunisvaara is the occurrence of the characteristic monzonite intrusive in the contact with the skarn horizon. Finally diabases, which seem to be widespread in the Kaunisvaara region, are unknown at Rautuvaara.

Acknowledgements - The authors are especially indebted to Prof. H. Paarma, Rautaruukki Oy Geological Research, for constructive remarks and for the permission to publish the present paper, to Drs G. Gaál and J. Nuutilainen for fruitful criticism, to A. Hattula for the geophysical interpretations, to T. Tukiainen for the petrographical determinations and to $V$. Suokonautio for the ADP-treatment of the tectonic data.

\section{REFERENCES}

Borgström, L. H. (1928) On the Iron ore of Juvakaisenmaa. Fennia 50 (20). 20 p.

Frietsch, R. (1966) Berggrund och malmer i Svappavaarafältet, Norra Sverige, English summary. Sveriges Geol. Unders. Ser. C. No. 604. 282 p.

Gaál, G. and Suokonautio, IV. (1973) An automatic data processing system for exploration mapping in Precambrian terrain: GEOKU. Geol. Survey of Finland Bull. 266. 26 p.

Lindroos, H. (1974) The Stratigraphy of the Kaunisvaara Iron Ore District, Northern Sweden. Sveriges Geol. Unders. Ser. C No. 695. 18 p.
Mikkola, E. (1941) Kivilajikartan selitys, B7-C7-D7 Muonio-Sodankylä-Tuntsajoki. English summary: Explanation to the Map of Rocks. The General Geological Map of Finland. 1: 400000. $286 \mathrm{p}$.

Mikkola, T. (1960) Kolarin rautamalmeista. Geologi 12 (8): 89-90.

Schmidt, K. (1960) Neue Eisenerze bei Kolari (Lappland). Zeitschr. für angew. Geol. 6 (1): $11-13$.

Serdyuchenko, D. P. (1975) Some Precambrian scapolite-bearing rocks evolved from evaporites. Lithos 8: $1-7$. 
Shaikh, A. (1964) Studien über das RautuvaaraErzgebiet. Dissertation. Universität Wien.

Stigzelius, H. and Ervamaa, P. (1962) Lapin kivennäisvarat. English Summary: Mineral Res- ources of Lapland. Geologinen tutkimuslaitos. Geotekn. Julk. 67. 56 p.

Mianuscript received, February 26, 1976. 